\title{
Tax expenditure in Croatia: personal income, corporate income, real estate transfers and value added tax
}

Bratić, Vjekoslav

Source / Izvornik: Occasional Paper Series, 2007, 11, 1 - 15

Journal article, Published version

Rad u časopisu, Objavljena verzija rada (izdavačev PDF)

https://doi.org/10.3326/ops.31

Permanent link / Trajna poveznica: https://urn.nsk.hr/urn:nbn:hr:242:884923

Rights / Prava: Attribution-NonCommercial-NoDerivatives 4.0 International/ImenovanjeNekomercijalno-Bez prerada 4.0 međunarodna

Download date / Datum preuzimanja: 2023-04-26

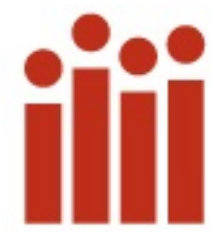

Repository / Repozitorij:

Institute of Public Finance Repository

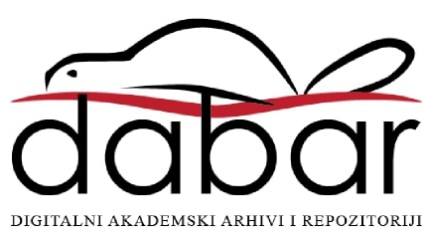


TAX EXPENDITURE IN CROATIA:

PERSONAL INCOME, CORPORATE INCOME, REAL ESTATE TRANSFERS AND VALUE ADDED TAX

Vjekoslav Bratić

Occasional Paper No. 31

December 2006 


\title{
TAX EXPENDITURE IN CROATIA: PERSONAL INCOME, CORPORATE INCOME, REAL ESTATE TRANSFERS AND VALUE ADDED TAX ${ }^{*}$
}

\author{
Vjekoslav Bratić \\ Institute of Public Finance, Zagreb \\ vieko@ijf.hr
}

JEL Classification: E62

1) The objective of this research was to show systematically all the items that represent tax expenditures in Croatia, within the systems of personal and corporate income tax, real estate transfer tax and value added tax, and to ascertain the real level of tax expenditures in terms of each individual form of tax in the period from 2001 to 2004. At the same time, this research should serve as a source of information on tax expenditure necessary for an analysis of the Croatian tax system and an assessment of its efficiency.

2) In addition to increasing the costs of revenue administration (for the administration of the tax reliefs), the introduction of various forms of tax reliefs into a taxation system necessarily reduces the revenue of the central government budget. A tax expenditure, unlike a subsidy, is contained in the reduced amount of the tax and is untransparent. We also hypothesize that tax expenditures in Croatia are high and tending to rise. Frequent changes in taxation because of the introduction of some form of tax expenditure cast doubt on the stability of the conditions of business. Because of this instability and inconstancy, they are not very well received in the entrepreneurial world.

3) For the purposes of this research, tax expenditures are defined as all items within the system of the existing forms of taxation that bring about a loss of revenue to the central government budget, whether because they reduce the tax base or the tax liability. Tax expenditures have various different forms. They can be tax deductions or allowances, tax exemptions, various forms of tax credits, tax privileges or reliefs and tax incentives.

4) The investigation used the data from the Tax Administration of the Republic of Croatia. Information about personal income tax were analysed on samples of $5 \%$ of the population and subsequently recalculated. The figures are given in the annexes.

5) Tables 1.1 to 1.5 present the results of the research. Table 1.1 shows that since 2001 the total nominal amounts of tax reliefs have been on the increase. The greatest nominal amounts of tax reliefs are found in personal income tax (total personal allowance) and in value added tax (zero rate deliveries).

6) Individual categories of tax expenditure in various taxes are not aggregated because assessments of their amount are obtained on the assumption that the other categories of tax expenditures and the behaviour of consumers, government policy and other factors are constant.

\footnotetext{
* This article represents a project abstract and is published in Croatian in the journal "Financial Theory and Practice", 30(2), 2006, pp. 103-113, and is downloadable in Croatian from: http://www.ijf.hr/FTP/2006/2/sazetak.pdf, and also in English from: http://www.ijf.hr/eng/FTP/2006/2/bratic.pdf
} 
7) Until 2000 there were only personal allowances in the personal income tax system. Since then some twenty new reliefs and allowances have been introduced, which have reduced the tax base and increased the complexity and costs of the tax administration. In Table 1.2 we show the losses of general budget and in Table 1.3 the losses of the central government budget in the personal income tax system. The greatest amounts of tax expenditure in personal income tax relate to the items that reduce the tax base, while no great expenditures have been made on reducing tax liability.

In most tax systems, personal allowances for the taxpayer and the taxpayer's dependents are not considered as tax expenditures, but are rather thought to be inherent to the system. The same principle was respected in this investigation. Personal and dependents allowances are not considered tax expenditures, but the amounts set aside for this purpose are registered for the sake of giving some insight into the amount and the social effect that is achieved through them.

The most important items for reducing the personal income tax base are the basic personal allowance (A1) and dependents allowances (A2). The sum of these provides the total personal allowances (A). Although these are not considered tax expenditures, we shall explain the results produced only to obtain a picture of what kind of burden on the central government budget and the general budget they are.

These total personal allowances (A) result in the greatest "loss" to the general budget. They range between the 7.7 billion kuna in 2001 to 9.3 billion kuna in 2004. Because of the basic personal allowance alone (A1) the general budget failed to collect more than 6 billion kuna in 2001 and 7.7 billion kuna in 2004.

Tax expenditures for other allowances (D) at all levels of government rose from 0.6 billion kuna in 2001 to more than a billion in 2004. At the top of the scale are D3 allowances (premiums for life insurance that have characteristics of savings, premiums for supplementary and private health insurance, and voluntary retirement insurance premiums), D5 (augmented depreciation costs), D10 (additional personal allowance for persons who live in the Areas of Special National Concern (PPDS $-1^{\text {st }}, 2^{\text {nd }}$ and $3^{\text {rd }}$ categories) and other areas specially treated for tax purposes (hill and mountain areas and islands), D13 (expenditures for satisfaction of housing requirements), D15 (lump-sum expenditures for taxpayers who have acquired some forms of income from assets) and D16 (lumpsum expenditures for tax payers who have earned personal income from some other independent activities), but with different trends. Expenditures for D3, D5, D10 and D13 are rising, while tax expenditures for D15 and D15 are falling.

There are no very significant expenditures in the context of the other items in the allowances.

At all levels of government small amounts are allocated for reductions of the tax liability (C), from 11 million in 2001 to 14 million in 2004.

In 2004, the central government budget lost 3.1 billion kuna because of the existence of the personal allowances for taxpayers (A1), and because of dependents allowances (A2) it lost almost 0.6 billion kuna.

Because of the total other allowances (D), the central government budget forfeited 417 million kuna in 2004. The greatest losses came within the additional personal allowances for persons who live in the PPDS and in other areas specially treated for tax purposes (D10, 125 million kuna), premiums for life insurance that have characteristics of savings, premiums for supplementary and private 
health insurance, and voluntary retirement insurance premiums (D3) and lump-sum expenditures for tax payers who have earned personal income from some other independent activities (D16), 60 million kuna each, and augmented depreciation costs (D5, 53 million kuna). Of the other tax expenditures in 2004, the expenditures for satisfaction of housing requirements (D13, 43 million kuna) and the lump-sum expenditures for taxpayers who have acquired some forms of income from assets (D15, 37 million kuna) stand out for their amounts.

Because of the relatively small amounts in comparison with the above mentioned items, other items in total allowances (D) do not have any significant impact.

Reductions of personal income tax due or tax credits (C) are not an important loss for the central government budget, because they came to only 5.6 million kuna in 2004, and were given to Croatian Wartime Military Disabled in proportion to degree of their disability.

8) In the profit or corporate income tax system, we analysed the reductions of the corporate income tax base (incentives for employment, for research and development (R\&D), for education, training and personal professional development) and reductions of tax due (incentives for investment - three kinds, depending on the employment period, number of employed, amount of investment and interest rate; incentives for occupational rehabilitation and the employment of disabled persons; reliefs and exemptions for the area of the city of Vukovar; reliefs and exemptions for Areas of Special National Concern (PPDS - $1^{\text {st }}, 2^{\text {nd }}$ and $3^{\text {rd }}$ categories) and hill and mountain areas; and reliefs and exemptions for free zone users - three kinds).

The total amounts that might have been collected in the corporate income tax system at all levels of government, but were not because of the reduction of the tax base and the reduction of tax due itself are rising year after year. While in 2001 these losses of general budget came to only 86 million kuna, in 2004 they were greater than 481 million kuna. Central government budget losses from corporate income tax outstanding are also rising, from 60 million kuna in 2001 to as much as 337 million kuna in 2004.

Lost tax revenue as a percentage of total central government budget corporate income tax revenue rose from $3 \%$ in 2001 to almost $11 \%$ in 2004. In other words, of the possible 100 kuna it might have collected in 2004 , the central government voluntarily forfeited 11 kuna in revenue from the corporate income tax.

9) From 2002 of 2003, the amount and number of claimants of various forms of exemptions from the payment of the real estate transfer tax rose, which means that the amounts of the revenue that the central government renounced also rose. These developments were mainly the result of the new statutory possibilities for reductions of tax due on real estate transfer provided in 2001.

The total amounts of exemptions, reductions of tax due on purchase of first peace of real estate and reductions of tax due for the Areas of Special National Concern (PPDS) at all levels of government (or losses of tax revenue of central and local units) rose from almost 18 million kuna in 2001 to as much as 303 million in 2004.

The lowest losses to central government budget revenue from real estate transfer tax were recorded in 2001, when they came to only 7 million kuna. After that, this category of tax expenditures rose rapidly, from 28 million kuna in 2002, to more than 121 million kuna in 2004. 
Lost tax revenue as a percentage of total central government budget real estate transfer tax revenue rose from $2.5 \%$ in 2001 to as much as 34\% in 2004 .

10) In the analysed period the domestic value added tax (VAT) system had two tax rates: $22 \%$ and $0 \%$. Ever increasing amounts of deliveries were made at the zero rate, which means that more central government budget revenue was being lost.

VAT tax expenditures resulting from the use of the zero rate rose from 3.9 billion kuna in 2001 to almost 5.2 billion kuna in 2004.

In spite of the rise in revenue from VAT (from 23 billion to almost 30 billion), the rise in expenditures is still greater. And expenditures as a percentage of total revenue from VAT have also been on the rise, from $16.7 \%$ in 2001 to $17.4 \%$ in 2004 .

11) The investigation encountered certain problems. The biggest problem was that there is an absence of any single and clear definition of tax expenditure in the world at large nor there exists any unified methodology for calculating tax expenditures. Apart from that, this research is the first, pioneering attempt to calculate tax expenditure in Croatia, i.e., how much the central government budget in Croatia loses in monetary terms via the various reliefs, exemptions and reductions in the four tax forms. We need more detailed analyses of tax expenditures in the whole of the tax system in the coming periods. In addition, the negative effects of the introduction of new tax forms should certainly be part of any future investigation into this topic.

12) Concrete recommendations for decision makers that stem from this investigation are:

- In order to respect the principles of transparency, tax expenditures ought to be included into the draft budget or into the regular process of making budgetary decisions.

- A special office ought to be formed within the Ministry of Finance that would regularly track and evaluate the effect and amounts of tax expenditures.

- Reports discussing the policy expenditure should be regularly prepared during budget preparation so that it becomes possible to opt for either tax expenditures or direct spending.

- Tax expenditures should be subject to the regular annual audit of the State Audit Office.

- Tax expenditures that have been introduced for special branches of the economy, regions or categories of the population should be re-examined, and if possible, reduced or abolished.

- Tax expenditures should have a precisely determined purpose, they should be properly and purposefully targeted, be based on real needs, and harmonised with the stated objects of the government in economic and social policy.

- Transfers to categories of the population whose welfare is at risk (veterans, the PPDS) should be transparent and well targeted.

- Precipitate and sudden changes in the tax laws must be avoided because they have a negative effect on economic decisions of taxpayers.

- The consistency, transparency and stability of the tax system, concomitant with respect for the principles of simplicity, efficiency and equity, should be enhanced by the abolition of existing and the non-introduction of new reliefs, deductions, privileges, reductions, exemptions or exceptions. This will have the effect of reducing the costs of the tax administration as well as reductions in the losses of all levels of the budget. 
- In any introduction of any potential new form of tax expenditure into the existing tax system, the emphasis must be placed on the cost-benefits of the introduction.

- Because of the relatively small amounts earmarked for some of the reliefs in the other allowances (D) in the personal income tax system- the untaxed receipts of artists, or exemptions and reliefs to private persons who carry out some artistic or cultural activity (D1), tax deductible entertainment costs (D6), research and development expenditures (D9), contributions for health insurance paid in the country (D11) and expenditures for donations for culture, art and the similar purposes (D14) - and because each relief increases the administrative burden of the tax authorities, the abolition of these reliefs should be considered.

- The reliefs in the taxation of corporate income tax in the Areas of Special National Concern (PPDS), the hill and mountains areas and the city of Vukovar need to be harmonised and gradually phased out totally because of the needs for harmonisation with the EU tax system.

The objective of this investigation was to ascertain the kinds and the amount of tax expenditures in the personal income tax, corporate income tax, real estate transfer tax and value added tax systems in the period from 2001 to 2004. A clear image of the tax expenditure agenda can help the tax authorities in an evaluation of the usefulness of the existence and effects of such an agenda, particularly when we take into account the losses from various tax reliefs and exemptions. At the same time, this research should be able to serve as a source of information on tax expenditures necessary for an analysis of the Croatian tax system and an evaluation of its effectiveness.

The research encountered numerous problems, such as the absence of any single, clear-cut definition of tax expenditures in the world at large, and of any uniform methodology for the calculation of tax expenditures, as well as the lack of similar investigations in the transition countries. It also has to be pointed out that this is the first investigation in the area of tax expenditures in Croatia, with all the problems of pioneering works.

In spite of these constraints, this first attempt at calculating tax expenditures has nevertheless been carried out, and in the future it should be expanded to cover the whole of the taxation system. We decided to consider as tax expenditures all those items within the existing forms of tax that constituted a loss to the central government budget by reducing either the tax base or the tax liability directly.

In spite of the existence of all the problems listed, the basic objective of the project has been met. The research has shown just how much revenue was not collected by the general and the central government budget because of the existence of tax expenditures. The basic result of the investigation is the conclusion that almost all the expenditure items in the systems of income, profit, real estate transfer and value added tax are constantly on the rise.

The research produced certain concrete recommendations for the decision makers.

- In order to respect the principles of transparency, tax expenditures ought to be included into the draft budget or into the regular process of making budgetary decisions.

- A special office ought to be formed within the Ministry of Finance that would regularly track and evaluate the effect and amounts of tax expenditures. 
- Reports discussing the policy expenditure should be regularly prepared during budget preparation so that it becomes possible to opt for either tax expenditures or direct spending.

- Tax expenditures should be subject to the regular annual audit of the State Audit Office.

- Tax expenditures that have been introduced for special branches of the economy, regions or categories of the population should be re-examined, and if possible, reduced or abolished.

- Tax expenditures should have a precisely determined purpose, they should be properly and purposefully targeted, be based on real needs, and harmonised with the stated objects of the government in economic and social policy.

- Transfers to categories of the population whose welfare is at risk (veterans, the PPDS) should be transparent and well targeted.

- Precipitate and sudden changes in the tax laws must be avoided because they have a negative effect on economic decisions of taxpayers.

- The consistency, transparency and stability of the tax system, concomitant with respect for the principles of simplicity, efficiency and equity, should be enhanced by the abolition of existing and the non-introduction of new reliefs, privileges, reductions, exemptions or exceptions. This will have the effect of reducing the costs of the tax administration as well as reductions in the losses of all levels of the budget.

- In any introduction of any potential new form of tax expenditure into the existing tax system, the emphasis must be placed on the cost-benefits of the introduction.

- Because of the relatively small amounts earmarked for some of the reliefs in the other allowances (D) in the personal income tax system- the untaxed receipts of artists, or exemptions and reliefs to private persons who carry out some artistic or cultural activity (D1), tax deductible entertainment costs (D6), research and development expenditures (D9), contributions for health insurance paid in the country (D11) and expenditures for donations for culture, art and the similar purposes (D14) and because each relief increases the administrative burden of the tax authorities, the abolition of these reliefs should be considered.

In further work, the tax authorities will have to pay particular attention to the harmonisation of the domestic system with EU requirements. By signing the Stabilisation and Association Agreement ${ }^{1}$ Croatia assumed the obligation to adjust tax exemptions that the European Commission considers not to be adjusted to the single market and not in line with the acquis. This refers in particular to given provisions of the Corporate Income Tax Law ${ }^{2}$ that govern the reliefs in the Areas of Special National Concern, in the hill and mountain areas and the city of Vukovar. These reliefs are looked upon as government aid and will have to be brought into line with the EU guidelines concerning government regional aid $^{3}$. So as to be able perhaps to retain fiscal (operational) aid regulated by the Law concerning the Areas of Special National Concern (PPDS), the Law concerning the Hill and Mountain Areas, and the City of Vukovar Law, it is necessary to demonstrate their specific purpose and to analyse their effects. Something similar

\footnotetext{
${ }^{1}$ Law ratifying the stabilisation and assocaition agreement between the Republic of Croatia and the European Community and the states members, NN, Treaties, 14/01, 14/02, 1/05

${ }^{2}$ Articles 21, 22 and 23 of the Corporate Income Tax Law, NN 177/04, which are not in harmony with articles 70 (iii) and 130 of the SAA.

${ }^{3}$ European Guidelines on National Regional Aid, 98/C; OJ C 77 of March 10, 1998.
} 
will be necessary concerning provisions about the VAT zero rate as well as in some other aspects of the Croatian tax system.

At the end we should reiterate: tax policy should not be used to carry out measures of social, economic or developmental policy, rather its basic purpose is to collect tax revenue for the financing of public needs as simply, efficiently and equitably as possible.

Since tax expenditures oppose the principles of simplicity, neutrality and efficiency in the tax system, they have to be investigated, tracked and re-examined in an ongoing programme of research.

Table 1.1 Nominal amounts of total tax reliefs from 2001 to 2004 of all levels of government

\begin{tabular}{|c|c|c|c|c|}
\hline & 2001 & 2002 & 2003 & 2004 \\
\hline \multicolumn{5}{|l|}{1 Personal income tax } \\
\hline 1.1 personal allowance & $42,803.0$ & $44,962.0$ & $49,414.0$ & $52,666.0$ \\
\hline 1.2 other allowances & $2,023.2$ & $2,598.0$ & $4,332.4$ & $4,897.9$ \\
\hline \multicolumn{5}{|l|}{2 Corporate income tax } \\
\hline $\begin{array}{l}\text { Reduction of the tax base } \\
2.1 \text { incentives for employment, } R \& D \text {, and training and } \\
\text { personal professional development }\end{array}$ & 178.4 & 298.0 & $1,255.1$ & $1,641.8$ \\
\hline $\begin{array}{l}\text { Reduction of tax due } \\
2.2 \text { reliefs and exemptions in the Areas of Special National } \\
\text { Concern (PPDS), in the city of Vukovar, for free zones } \\
\text { users, investment incentives and incentives for } \\
\text { occupational rehabilitation and the employment of } \\
\text { disabled persons }\end{array}$ & 50.6 & 63.3 & 122.9 & 152.9 \\
\hline \multicolumn{5}{|l|}{3 Real estate transfer tax } \\
\hline 3.1 amount of exemptions from the payment of the tax & 17.9 & 33.8 & 57.8 & 72.1 \\
\hline $\begin{array}{l}3.2 \text { reduction of tax due on purchase of first peace of real } \\
\text { estate }\end{array}$ & 0 & 12.2 & 174.1 & 194.3 \\
\hline 3.3 reduction of tax due for the PPDS & 0 & 24.8 & 38.1 & 55.0 \\
\hline \multicolumn{5}{|l|}{4 VAT } \\
\hline 4.1 deliveries not subject to taxation & $15,773.0$ & $17,018.5$ & $19,876.6$ & $21,124.2$ \\
\hline 4.2 deliveries exempted from taxation & $36,447.2$ & $39,679.1$ & $42,070.1$ & $49,397.9$ \\
\hline 4.3 zero rated deliveries & $17,582.7$ & $19,331.3$ & $21,491.7$ & $23,502.8$ \\
\hline
\end{tabular}

Source: Tax Administration - Central office, Ministry of Finance 
Table 1.2 Total tax expenditures in personal income tax for all levels of government, 2001-2004, real amounts (in million kuna)

\begin{tabular}{|c|c|c|c|c|}
\hline Personal income tax & 2001 & 2002 & 2003 & 2004 \\
\hline \multicolumn{5}{|l|}{ I Reduction of the tax base } \\
\hline Total other allowances $(D)$ & 616.7 & 628.7 & 939.3 & $1,042.2$ \\
\hline $\begin{array}{l}\text { D1 untaxed receipts of artists, or exemptions and reliefs to } \\
\text { private persons who carry out some artistic or cultural } \\
\text { activity }\end{array}$ & 0.0 & 0.1 & 0.1 & 0.0 \\
\hline D2 the untaxed part of an artistic royalty or fee & 8.0 & 7.1 & 6.3 & 8.1 \\
\hline $\begin{array}{l}\text { D3 premiums for life insurance that have characteristics of } \\
\text { savings, premiums for supplementary and private health } \\
\text { insurance, and voluntary retirement insurance premiums }\end{array}$ & 22.9 & 87.4 & 123.0 & 149.0 \\
\hline D4 income reduction in the PPDS and the city of Vukovar & 16.5 & 19.9 & 21.7 & 44.7 \\
\hline D5 accelerated depreciation costs & 62.5 & 82.6 & 189.5 & 133.2 \\
\hline D6 tax deductible entertainment costs & 1.4 & 0.5 & 1.8 & 0.7 \\
\hline $\begin{array}{l}\text { D7 salaries paid out for newly hired staff and rewards to } \\
\text { pupils doing practical work }\end{array}$ & 7.4 & 16.8 & 19.7 & 18.5 \\
\hline $\begin{array}{l}\text { D8 expenditure for training and personal professional } \\
\text { development of staff }\end{array}$ & - & - & 1.9 & 2.5 \\
\hline D9 R \& D expenditure & - & - & 0.0 & 0.2 \\
\hline $\begin{array}{l}\text { D10 additional personal allowance for people living in the } \\
\text { PPDS and other similar areas }\end{array}$ & 90.0 & 117.0 & 261.9 & 311.3 \\
\hline D11 contribution for health insurance paid in the country & - & - & 0.1 & 0.1 \\
\hline D12 expenditure for healthcare services & - & - & 9.7 & 22.9 \\
\hline D13 expenditure for housing requirements & - & - & 67.7 & 108.6 \\
\hline D14 expenditure for donations for culture, art and the like & 1.4 & 0.8 & 1.4 & 0.9 \\
\hline $\begin{array}{l}\text { D15 lump-sum expenditures for taxpayers who have } \\
\text { acquired some forms of income from assets }\end{array}$ & 210.8 & 87.8 & 85.9 & 92.5 \\
\hline $\begin{array}{l}\text { D16 lump-sum expenditures for taxpayers who have earned } \\
\text { personal income from some other independent activities }\end{array}$ & 195.9 & 208.7 & 148.7 & 149.1 \\
\hline Total personal allowance $(A)$ & $7,710.4$ & $8,142.9$ & $8,644.2$ & $9,312.7$ \\
\hline A1 basic personal allowance of the taxpayer & $6,192.8$ & $6,521.3$ & $7,196.6$ & $7,649.8$ \\
\hline A2 additional personal allowance for dependents & $1,517.6$ & $1,621.6$ & $1,447.7$ & $1,662.9$ \\
\hline II. Reduction of tax due (C) & 11.5 & 8.3 & 10.7 & 14.1 \\
\hline C1 tax credit for Croatian Wartime Military Disabled & 11.5 & 8.3 & 10.7 & 14.1 \\
\hline
\end{tabular}

Source: author's calculations 
Table 1.3 Loss of central government budget revenues on the basis of tax expenditures in personal income tax from 2001 to 2004 (in million kuna)

\begin{tabular}{|c|c|c|c|c|}
\hline & 2001 & 2002 & 2003 & 2004 \\
\hline \multicolumn{5}{|l|}{ I Reduction of the tax base } \\
\hline Total other allowances $(D)$ & 326.9 & 295.5 & 403.9 & 416.9 \\
\hline $\begin{array}{l}\text { D1 untaxed receipts of artists, or exemptions and reliefs to } \\
\text { private persons who carry out some artistic or cultural activity }\end{array}$ & 0.0 & 0.1 & 0.04 & 0.0 \\
\hline D2 the untaxed part of an artistic royalty or fee & 4.2 & 3.3 & 2.7 & 3.2 \\
\hline $\begin{array}{l}\text { D3 premiums for life insurance that have characteristics of } \\
\text { savings, premiums for supplementary and private health } \\
\text { insurance, and voluntary retirement insurance premiums }\end{array}$ & 12.1 & 41.1 & $52 ., 9$ & 59.6 \\
\hline D4 income reduction in the PPDS and the city of Vukovar & 8.7 & 9.4 & 9.3 & 17.9 \\
\hline D5 accelerated depreciation costs & 33.1 & 38.8 & 81.5 & 53.3 \\
\hline D6 tax deductible entertainment costs & 0.7 & 0.2 & 0.8 & 0.3 \\
\hline $\begin{array}{l}\text { D7 salaries paid out for newly hired staff and rewards to } \\
\text { pupils doing practical work }\end{array}$ & 3.9 & 7.9 & $8 ., 5$ & 7.4 \\
\hline $\begin{array}{l}\text { D8 expenditure for training and personal professional } \\
\text { development of staff }\end{array}$ & - & - & 0.8 & 1.0 \\
\hline D9 R \& D expenditure & - & - & 0.0 & 0.1 \\
\hline $\begin{array}{l}\text { D10 additional personal allowance for people living in the } \\
\text { PPDS and other similar areas }\end{array}$ & 47.7 & 55.0 & 112.6 & 124.5 \\
\hline D11 contribution for health insurance paid in the country & - & - & 0.04 & 0.04 \\
\hline D12 expenditure for healthcare services & - & - & 4.2 & 9.2 \\
\hline D13 expenditure for housing requirements & - & - & 29.1 & 43.4 \\
\hline D14 expenditure for donations for culture, art and the like & 0.7 & 0.4 & 0.6 & 0.4 \\
\hline $\begin{array}{l}\text { D15 lump-sum expenditures for taxpayers who have acquired } \\
\text { some forms of income from assets }\end{array}$ & 111.7 & 41.3 & 36.9 & 37.0 \\
\hline $\begin{array}{l}\text { D16 lump-sum expenditures for taxpayers who have earned } \\
\text { personal income from some other independent activities }\end{array}$ & 103.8 & 98.1 & 63.9 & 59.6 \\
\hline Total personal allowance $(A)$ & $4,086.5$ & 3.827 .2 & $3,717.0$ & $3,725.1$ \\
\hline A1 basic personal allowance of the taxpayer & $3,282.2$ & $3,065.0$ & $3,094.5$ & $3,059.9$ \\
\hline A2 additional personal allowance for dependents & 804.3 & 762.2 & 622.5 & 665.2 \\
\hline II. Reduction of tax due (C) & 6.1 & 3.9 & 4.6 & 5.6 \\
\hline C1 tax credit for Croatian Wartime Military Disabled & 6.1 & 3.9 & 4.6 & 5.6 \\
\hline
\end{tabular}

Source: author's calculation 
Table 1.4 Total tax expenditures in corporate income tax and real estate transfer tax at all levels of government from 2001 to 2004 (in million kuna)

\begin{tabular}{|c|c|c|c|c|}
\hline & 2001 & 2002 & 2003 & 2004 \\
\hline \multicolumn{5}{|l|}{ Corporate income tax - reduction of tax due } \\
\hline $\begin{array}{l}\text { incentives for employment, research and development, } \\
\text { and for training and personal professional development } \\
\text { x } 20 \%\end{array}$ & 35.7 & 59.6 & 251.0 & 328.4 \\
\hline $\begin{array}{l}\text { reliefs and exemptions in the PPDS, the city of } \\
\text { Vukovar, for free zones users, investment incentives } \\
\text { and incentives for occupational rehabilitation and the } \\
\text { employment of disabled persons }\end{array}$ & 50.6 & 63.3 & 122.9 & 152.9 \\
\hline \multicolumn{5}{|l|}{ Real estate transfer - reduction of tax due } \\
\hline amount of exemptions from the payment of the tax & 17.8 & 33.8 & 57.8 & 53.7 \\
\hline $\begin{array}{l}\text { reduction of tax due on purchase of the first peace of } \\
\text { real estate }\end{array}$ & 0 & 12.2 & 174.1 & 194.3 \\
\hline tax reductions for the PPDS & 0 & 24.8 & 38.1 & 55.0 \\
\hline
\end{tabular}

Source: author's calculations

Table 1.5 Lost central government budget revenues pursuant to tax expenditures in corporate income tax and real estate transfer tax from 2001 to 2004 (in million kuna)

\begin{tabular}{|l|r|r|r|r|}
\hline & $\mathbf{2 0 0 1}$ & $\mathbf{2 0 0 2}$ & $\mathbf{2 0 0 3}$ & $\mathbf{2 0 0 4}$ \\
\hline corporate income tax & 60.3 & 86.0 & 261.7 & 336.9 \\
\hline real estate transfer tax & 7.1 & 28.3 & 108.0 & 121.2 \\
\hline
\end{tabular}

Source: author's calculation

Table 1.6 Nominal amounts and losses of central government budget revenues on the basis of tax expenditures in the value added tax system from 2001 to 2004 (in billion kuna)

\begin{tabular}{|l|r|r|r|r|}
\hline & $\mathbf{2 0 0 1}$ & $\mathbf{2 0 0 2}$ & $\mathbf{2 0 0 3}$ & $\mathbf{2 0 0 4}$ \\
\hline zero rated deliveries & 17.6 & 19.3 & 21.5 & 23.5 \\
\hline $\begin{array}{l}\text { lost central government budget VAT revenues of the } \\
\text { zero rate }\end{array}$ & 3.9 & 4.3 & 4.7 & 5.2 \\
\hline
\end{tabular}

Source: author's calculation 
INSTITUTE OF PUBLIC FINANCE - OCCASIONAL PAPER SERIES

\begin{tabular}{|c|c|}
\hline No. 1 & $\begin{array}{l}\text { State Intervention for Growth Promotion in Market Economies } \\
\text { Marina Kesner Škreb, January } 1997\end{array}$ \\
\hline No. 2 & $\begin{array}{l}\text { Estimate of Revenues from the Value Added Tax in the Republic of Croatia } \\
\text { Danijela Kuliš and Žarko Miljenović, October } 1997\end{array}$ \\
\hline No. 3 & $\begin{array}{l}\text { The Unofficial Economy in Croatia: Causes, Size and Consequences } \\
\text { Ivo Bićanić and Katarina Ott, November } 1997\end{array}$ \\
\hline No. 4 & $\begin{array}{l}\text { Price Effects of VAT Introduction in Croatia } \\
\text { Martina Dalić, December } 1997\end{array}$ \\
\hline No. 5 & $\begin{array}{l}\text { Tax Administration Reform in Transition: The Case of Croatia } \\
\text { Katarina Ott, April } 1998\end{array}$ \\
\hline No. 6 & $\begin{array}{l}\text { The Present Sate of the Croatian Public Debt } \\
\text { Zoran Bubaš, December } 1998\end{array}$ \\
\hline No. 7 & $\begin{array}{l}\text { Public Investment in Croatia } \\
\text { Katarina Ott and Anto Bajo, March } 1999 .\end{array}$ \\
\hline No. 8 & $\begin{array}{l}\text { Welfare Policy and Social Transfers in Croatia } \\
\text { Predrag Bejaković and Alastair McAuley, July } 1999\end{array}$ \\
\hline No. 9 & $\begin{array}{l}\text { Is Unofficial Economy a Source of Corruption? } \\
\text { Vedran Šošić and Michael Faulend, November } 1999\end{array}$ \\
\hline No. 10 & $\begin{array}{l}\text { Banking Sector Problems: Causes, Resolutions and Consequences } \\
\text { Ljubinko Jankov, March } 2000\end{array}$ \\
\hline No. 11 & $\begin{array}{l}\text { Toward a Long - Term Strategy of Economic Development of Croatia: Where to Begin, What to Do, and } \\
\text { How to Do It? } \\
\text { Dubravko Mihaljek, June } 2001\end{array}$ \\
\hline No. 12 & $\begin{array}{l}\text { The Underground Economy in Croatia } \\
\text { Katarina Ott, March } 2002\end{array}$ \\
\hline No. 13 & $\begin{array}{l}\text { An Estimate of the Extent of Tax Evasion in Croatia } \\
\text { Sanja Madžarević Šujster, April } 2002\end{array}$ \\
\hline No. 14 & $\begin{array}{l}\text { Opportunism, Institutions and Moral Costs: The Socio - Cultural Dimension of the Underground } \\
\text { Economy in Croatia } 1995 \text { - } 1999 \\
\text { Aleksandar Štulhofer and Ivan Rimac, April } 2002\end{array}$ \\
\hline No. 15 & $\begin{array}{l}\text { Dollarisation and the Underground Economy: Accidental Partners? } \\
\text { Vedran Šošić and Michael Faulend, April } 2002\end{array}$ \\
\hline No. 16 & $\begin{array}{l}\text { Decentralization in the Republic of Croatia - A City Budget in the Period from } 1996 \text { to } 2000 \\
\text { Mihaela Pitarević, March } 2003\end{array}$ \\
\hline No. 17 & $\begin{array}{l}\text { Inequality in Croatia in the Period from } 1973 \text { to } 1998 \\
\text { Danijeli Nestić, April } 2003\end{array}$ \\
\hline
\end{tabular}




\begin{tabular}{|c|c|}
\hline No. 18 & $\begin{array}{l}\text { State Aid to Enterprises in Croatia in } 2001 \\
\text { Marina Kesner-Škreb, Ivana Pleše and Mia Mikić, October } 2003\end{array}$ \\
\hline No. 19 & $\begin{array}{l}\text { The Role of Parliament in the Budgetary Process - The Example of } \\
\text { the Croatian Parliament } \\
\text { Vjekoslav Bratić, October } 2004\end{array}$ \\
\hline No. 20 & $\begin{array}{l}\text { Local Government Unit Borrowing in Croatia: Opportunities and Constraints } \\
\text { Anto Bajo, October } 2004\end{array}$ \\
\hline No. 21 & $\begin{array}{l}\text { The Costs of Customs Compliance in Croatia in } 2001 \\
\text { Mihaela Bronić, November } 2004\end{array}$ \\
\hline No. 22 & $\begin{array}{l}\text { Tax Compliance Cost of Small Business in Croatia } \\
\text { Helena Blažić, November } 2004\end{array}$ \\
\hline No. 23 & $\begin{array}{l}\text { The Compliance Costs of Excise Duties in Croatia } \\
\text { Danijela Kuliš, November } 2004\end{array}$ \\
\hline No. 24 & $\begin{array}{l}\text { The Administrative Costs of Taxation and Customs Clearing in Croatia, 1999-2001 } \\
\text { Vjekoslav Bratić and Mihaela Bronić, November } 2004\end{array}$ \\
\hline No. 25 & $\begin{array}{l}\text { Fiscal Decentralization in Croatia: Problems of Fiscal Equalization } \\
\text { Anto Bajo and Mihaela Bronić, May } 2005\end{array}$ \\
\hline No. 26 & $\begin{array}{l}\text { Income Distribution in Croatia: What Do the Household Budget Survey Data Tell Us? } \\
\text { Danijel Nestić, June } 2005\end{array}$ \\
\hline No. 27 & $\begin{array}{l}\text { Impact of Foreign Direct Investment on Croatian Manufacturing Exports } \\
\text { Goran Vukšić, June } 2006\end{array}$ \\
\hline No. 28 & $\begin{array}{l}\text { Managing the Cash and Liquidity of the Croatian Budget } \\
\text { Anto Bajo, June } 2006\end{array}$ \\
\hline No. 29 & $\begin{array}{l}\text { The Quality of Governance and Economic Growth in Croatia } \\
\text { Marijana Bađun, June } 2006\end{array}$ \\
\hline No. 30 & $\begin{array}{l}\text { Can Capital Income Tax Improve Welfare in an Incomplete Market Economy with Labor-Leisure } \\
\text { Decision? } \\
\text { Danijela Medak Fell, December } 2006\end{array}$ \\
\hline No. 31 & $\begin{array}{l}\text { Tax Expenditure in Croatia: Personal Income, Corporate Income, Real Estate Transfers and Value } \\
\text { Added Tax } \\
\text { Vjekoslav Bratić, December } 2006\end{array}$ \\
\hline
\end{tabular}




\section{ABOUT THE INSTITUTE OF PUBLIC FINANCE}

The Institute of Public Finance (Zagreb, Croatia) founded in 1970, is a public institution dealing with research in the field of public sector economics, but also in applied and theoretical research on broader set of economic topics such as economic growth and development, role of institutions, transition to the market economy and EU integration. The empirical analysis is preferably related, but not limited, to experience of countries in Central and Eastern Europe and Southeast Europe.

\section{SELECTED LIST OF PUBLICATION (in English)}

\section{Serial publications}

- Financial Theory and Practice

- Occasional Paper Series

- Newsletter

\section{Books}

- Croatian Accession to the European Union: Facing the Challenges of Negotiations, editor Katarina Ott, 2005.

- The competitiveness of Croatia's human resources, editors Predrag Bejaković and Joseph Lowther, 2004.

- Croatian Accession to the European Union: Institutional Challenges, editor Katarina Ott, 2004.

- The Croatian Tax System, editor Mirjana Jerković, 2003.

- Croatian Accession to the European Union: Economic and Legal Challenges, editor Katarina Ott, 2003.

- The Citizen's Guide to Taxation, Marina Kesner-Škreb and Danijela Kuliš, 2001, (updated online).

- A Citizen's Guide to the Budget, editor Katarina Ott, 2000.

For further insight in our publications and ordering information please visit:

http://www.ijf.hr/eng/index.html. 